\title{
BERBAGAI MANFAAT DARI UPAYA MEMPERTAHANKAN ERGONOMIC PADA BERBAGAI POSISI GUNA UNTUK KESELAMATAN PASIEN
}

\author{
Yudistira Sianipar \\ yudistirasianipar01@gmail.com
}

\begin{abstract}
ABSTRAK
Ergonomic adalah komponen kegiatan dalam ruang lingkup hiperkes yang antara lain meliputi penyerasian pekerjaan terhadap tenaga kerja secara timbal balik untuk efisiensi dan kenyamanan kerja. Keselamatan Pasien adalah suatu sistem yang membuat asuhan pasien lebih aman, meliputi asesmen risiko, identifikasi dan pengelolaan risiko pasien, pelaporan dan analisis insiden, kemampuan belajar dari insiden dan tindak lanjutnya, serta implementasi solusi untuk meminimalkan timbulnya risiko dan mencegah terjadinya cedera yang disebabkan oleh kesalahan akibat melaksanakan suatu tindakan atau tidak mengambil tindakan yang seharusnya diambil. Standar Keselamatan Pasien wajib diterapkan fasilitas pelayanan kesehatan seperti rumah sakit dan penilaiannya dilakukan dengan menggunakan Instrumen Akreditasi (Akreditasi Rumah Sakit). Berbagai aktivitas pasien seperti cara berjalan, duduk, berdiri,mengangkat dan memindahkan sesuatu dari satu posisi ke posisi yang lain, dipantau dan dikoordinasikan oleh perawat dengan kondisi pasien agar menjangkau keselamatan pasien di Rumah Sakit. Seorang perawat dalam memberikan asuhan keperawatan harus memiliki pengetahuan yang benar, keterampilan, dan sikap untuk menangani kompleksitas perawatan kesehatan. Maka peranan perawat dalam hal menjaga keselamatan pasien sangatlah penting.

Kata kunci : Upaya Mempertahankan Ergonomic Pada Beberapa Posisi, Peran Perawat, Keselamatan Pasien.
\end{abstract}




\section{LATAR BELAKANG}

Keselamatan pasien rumah sakit adalah suatu sistem yang diterapkan untuk mencegah terjadinya cedera akibat perawatan medis dan kesalahan pengobatan melalui suatu sistem assesment resiko, identifikasi dan pengelolaan faktor risiko, pelaporan dan analisis insiden, kemampuan belajar dan tindak lanjut dari insident serta implementasi solusi untuk meminimalkan timbulnya risiko (Dep Kes RI, 2006).

Keselamatan pasien merupakan suatu sistem untuk mencegah terjadinya cedera yang disebabkan oleh kesalahan akibat melaksanakan suatu tindakan atau tidak mengambil tindakan yang seharusnya diambil (TKPRS RSUP Sanglah Denpasar, 2011).

Taylor, et al. (1993) mengungkapkan bahwa keperawatan merupakan profesi yang berfokus kepada pelayanan dan bertujuan membantu pasien mencapai kesehatannya secara optimal. Oleh karena itu pada saat memberikan asuhan keperawatan kepada pasien, perawat harus mampu memastikan bahwa pelayanan keperawatan yang diberikan mengedepankan keselamatan. Perawat harus memiliki kesadaran akan adanya potensi bahaya yang terdapat di lingkungan pasien melalui pengidentifikasian bahaya yang mungkin terjadi selama berinteraksi dengan pasien selama 24 jam penuh, karena keselamatan pasien dan pencegahan terjadinya cedera merupakan salah satu tanggung jawab perawat selama pemberian asuhan keperawatan berlangsung.

Berbagai aktivitas yang dapat diakukan pasien seperti berjalan, duduk, berdiri,mengangkat dan berpindah dari satu posisi ke posisi yang lain,hal ini dipantau dan dikoordinasikan oleh perawat agar menjangkau keselamatan pasien di Rumah Sakit.

Menjadi seorang perawat dalam memberikan asuhan keperawatan harus memiliki pengetahuan yang benar, keterampilan, dan sikap untuk menangani kompleksitas perawatan kesehatan. Tanpa pengetahuan yang memadai, tenaga kesehatan termasuk perawat tidak bisa menerapkan dan mempertahankan budaya keselamatan pasien.

Gerakan Keselamatan Pasien Rumah Sakit atau yang dikenal dengan sebutan patient safety merupakan suatu proses pemberian pelayanan rumah sakit terhadap pasien yang lebih aman. Proses ini mencegah terjadinya cedera yang disebabkan oleh kesalahan akibat melaksanakan suatu tindakan atau tidak mengambil tindakan yang seharusnya 
diambil. Tujuan utama penerapan patient safety di rumah sakit adalah mencegah dan mengurangi terjadinya Insiden Keselamatan Pasien dalam pelayanan kesehatan.

Banyak dari para perawat yang tidak mengetahui apa fungsinya di rumah sakit,mereka hanya mengira bahwa yang terpenting sudah bekerja dan bisa menghasilkan uang.Padahal disini sudah jelas tertera bahwa mereka adalah fondasi dalam menjaga keselamatan pasien,mereka yang lebih lama berada dengan pasien daripada tenaga medis lainya.Jadi para perawat diharsukan dalam mengetahui bagaimana upaya mempertahankan ergonomic dalam berbagai posisi pasien guna menjaga keselamatan pasien.

\section{METODE}

Metode yang digunakan disini adalah Literature review yang melakukan analisa dan kajian bebas terhadap artikel, buku, koran, majalah, jurnal print maupun jurnal online, Thesis, disertasi, text book, maupun ebook yang sesuai dan berfokus pada berbagai manfaat dari upaya mempertahankan ergonomic pada berbagai posisi guna untuk keselamatan pasien yang harus dimiliki oleh perawat guna untuk menghindari berbagai kecelakaan dalam menjalankan tugasnya. Adapun artikel yang digunakan pada literature review ini adalah artikel yang didapatkan dengan memuat 3 database Pubmed, Geogle Scholar dan Science Direct dengan memasukkan kata kunci "Upaya Mempertahankan Ergonomic Pada Beberapa Posisi", "Peran Perawat", "Keselamatan Pasien”. Artikel yang digunakan 10 referensi dengan tahun paling tua tahun 2012.

\section{HASIL}

Berdasarkan hasil pencarian literature review dengan menganalis buku, majalah, koran, jurnal print maupun jurnal online, Thesis, disertasi, didapatkan bahwa dalam berbagai manfaat dari upaya mempertahankan ergonomic pada berbagai posisi guna untuk keselamatan pasien sangat membawa perubahan besar dalam sebuah rumah sakit. Karena dalam sebuah rumah sakit, kesenangan dan kenyamanan pasien serta keluarga pasien adalah yang terpenting.

Ergonomi mempelajari perilaku manusia dalam kaitannya dengan pekerjaan manusia. Sasaran penelitian ergonomi ialah manusia pada saat bekerja dalam lingkungan. Secara singkat dapat dikatakan bahwa ergonomi ialah penyesuaian tugas pekerjaan dengan kondisi tubuh manusia ialah untuk menurunkan stress atau tekanan yang akan dihadapi. Salah satu upaya yang dilakukan antara lain menyesuaikan ukuran 
tempat kerja dengan dimensi tubuh agar tidak melelahkan, pengaturan suhu, cahaya dan kelembapan. Hal ini bertujuan agar sesuai dengan kebutuhan tubuh manusia. Ada salah satu definisi yang menyebutkan bahwa ergonomi bertujuan untuk "fitting the job to the worker".

$$
\text { Pelaksanaan dan penerapan }
$$
ergonomi di tempat kerja di mulai dari yang sederhana dan pada tingkat individual terlebih dahulu. Rancangan ergonomi akan dapat meningkatkan efisiensi, efektivitas dan produktivitas kerja, serta dapat menciptakan system serta lingkungan yang cocok, aman, nyaman dan sehat.Terutama dalam hal menjaga keselamatan pasien,jadi kedua belah pihak sama-sama di untungkan disini.

Adapun tujuan penerapan ergonomic adalah sebagai berikut .

1. Meningkatkan kesejahteraan fisik dan mental dengan meniadakan beban kerja tambahan (fisik dan mental), mencegah penyakit akibat kerja, dan meningkatkan kepuasan kerja.

2. Meningkatkan kesejahteraan social dengan jalan meningkatkan kualitas kontak sesama pekerja, pengorganisasian yang lebih baik dan menghidupkan system kebersamaan dalam tempat kerja.

3. Berkontribusi di dalam keseimbangan rasional antara aspekaspek teknik, ekonomi, antropologi dan budaya

Dan manfaat ergonomi yang dapat kita temukan adalah :

1. Menurunnya angka kesakitan akibat kerja.

2. Menurunnya kecelakaan kerja.

3. Biaya pengobatan dan kompensasi berkurang.

4. Stress akibat kerja berkurang.

5. Produktivitas membaik.

6. Alur kerja bertambah baik.

7. Rasa aman karena bebas dari gangguan cedera.

8. Kepuasan kerja meningkat

Berdasarkan potensi bahaya di RS dan untuk mencegah dan mengurangi resiko bahaya cidera, maka perlu ditetapkan standar Keselamatan dan Kesehatan Kerja di RS (K3RS). Ditetapkannya standar K3RS dikarenakan pekerja rumah sakit serta klien/pasien memiliki risiko lebih tinggi mengalami penyakit dan kecelakaan. Secara global,petugas kesehatan terutama perawat maupun pasien berisiko tinggi untuk terkena gangguan musculoskeletal.Salah satu potensi bahaya di rumah sakit yang 
menyebabkan musculoscletal adalah faktor ergonomic.Maka ketelitian dan kecekatan perawat dalam bekerja harus dikemabangkan,tuntutan dan kondisi yang mengharuskan hal tersebut. Karena guna dari hal itu adalah untuk keselamatan dan kesejahteraan pasien di RS (Rumah Sakit).

\section{PEMBAHASAN}

Seorang perawat dalam memberikan asuhan keperawatan harus memiliki pengetahuan yang baik, keterampilan, dan sikap untuk menangani kompleksitas perawatan kesehatan. Tanpa pengetahuan yang memadai, tenaga kesehatan termasuk perawat tidak bisa menerapkan dan mempertahankan budaya keselamatan pasien.

Berdasarkan laporan IOM tahun 1999 tentang masalah keselamatan pasien yang menghebohkan dunia kesehatan mendorong banyak pihak berupaya melakukan hal untuk memperbaiki kualitas pelayanan terutama yang berhubungan dengan keselamatan pasien.

Keselamatan pasien merupakan suatu sistem untuk mencegah terjadinya cedera yang disebabkan oleh kesalahan akibat melaksanakan suatu tindakan atau tidak mengambil tindakan yang seharusnya diambil. Perawat harus memiliki kesadaran akan adanya potensi bahaya yang terdapat di lingkungan pasien melalui pengidentifikasian bahaya yang mungkin terjadi selama berinteraksi dengan pasien selama 24 jam penuh, karena keselamatan pasien dan pencegahan terjadinya cedera merupakan salah satu tanggung jawab perawat selama pemberian asuhan keperawatan berlangsung.

Salah satu cedera yang terjadi pada pasien adalah dikarenakan tidak dapat menerapkan kondisi egronomik yang baik. Ergonomi adalah suatu aturan atau norma dalam sistem kerja. Di Indonesia memakai istilah ergonomi, tetapi di beberapa Negara seperti di Skandinavia menggunakan istilah "Bioteknologi" sedangkan di Negara Amerika menggunakan istilah "Human Engineering"atau "Human Factors Engineering". Namun demikian, kesemuanya membahas hal yang sama yaitu tentang optimalisasi fungsi manusia terhadap aktivitas dilakukan.

Tujuan penerapan sistem keselamatan pasien di rumah sakit antara lain:

1. Terciptanya budaya keselamatan pasien dirumah sakit

2. Meningkatnya akuntabilitas rumah sakit terhadap pasien dan masyarakat.

3. Menurunnya Kejadian Tak Diharapkan (KTD) 
4. Terlaksananya program pencegahan sehingga tidak terjadi pengulangan KTD Dalam upaya pencapaian tujuan keselamatan pasien ini, setiap rumah sakit

Program keselamatan pasien ini memberikan berbagai manfaat bagi rumah sakit antara lain:

a. adanya kecenderungan "Green Product" produk yang aman di bidang industri lain seperti halnya menjadi persyaratan dalam berbagai proses transaksi, sehingga suatu produk menjadi semakin laris dan dicari masyarakat.

b. Rumah Sakit yang menerapkan keselamatan pasien akan lebih mendominasi pasar jasa bagi Perusahaan-perusahaan dan Asuransi-asuransi dan menggunakan Rumah Sakit tersebut sebagai provider kesehatan karyawan/klien mereka, dan kemudian di ikuti oleh masyarakat untuk mencari Rumah Sakit yang aman.

c. Kegiatan Rumah Sakit akan lebih memukuskan diri dalam kawasan keselamatan pasien.

Asuhan keperawatan adalah kegiatan profesional perawat yang bersifat dinamis dan membutuhkan kreativitas mereka memberikan pelayanan kepada pasien. Askep yang diberikan kepada pasien merupakan pelayanan profesional untuk membantu pasien secara komprehensif melakukan kegiatan rutinnya tanpa bantuan orang lain. Dalam penelitian ini subvariabel Askep diukur dengan indikator melaksanakan askep sesuai dengan SOP dan menerapkan Askep sesuai dengan indikator kinerja klinik.

Secara umum tujuan dari penerapan ergonomik adalah :

a. Meningkatkan kesejahteraan fisik dan mental melalui upaya pencegahan cedera dan penyakit akibat kerja, menurunkan beban kerja fisik dan mental, mengupayakan promosi dan kepuasan kerja.

b. Meningkatkan kesejahteraan sosial melalui peningkatan kualitas kontak sosial, mengelola dan mengordinir kerja secara tepat guna dan meningkatkan jaminan sosial baik selama kurun waktu usia produktif maupun setelah tidak produktif.

c. Menciptakan keseimbangan rasional antara berbagai aspek yaitu aspek teknis, ekonomis, antropologis, dan budaya dari setiap sistem kerja yang 
dilakukan sehingga tercipta kualitas

kerja dan kualitas hidup yang tinggi.

Berikut akan kita lihat beberapa posisi pada pasien yang baik dilakukan untuk menjaga keselamatanya.

\section{A.Sikap Berbaring}

Posisi klien penting telentang

1. Dorsal RACKBIKE (tergeletak di belakang), rawan (berbaring pada perut).

2. Sims (semi-rawan-berbaring di samping [biasanya kiri] — dengan atas lutut tertekuk).

3. Fowler di (tergeletak di belakang, dengan kepala tinggi), lutut-dada atau genupectoral (berbaring di lutut, dengan dada beristirahat di tempat tidur).

4. Dorsal lithotomy (tergeletak di belakang, dengan kaki di sanggurdi), dan lateral (berbaring di samping). Posisi telentang dapat dimodifikasi dengan menekuk lutut dan menempatkan kaki datar di tempat tidur.

5. Trendelenburg's (posisi kepaladown - berbaring dengan kepala lebih rendah dari kaki)-digunakan untuk mengobati sengatan, dengan mempromosikan aliran darah ke otak. Posisi ini juga digunakan untuk beberapa bagian dari postural drainase, untuk membantu mengeringkan sekresi dari segmen paru-paru.

\section{B.Sikap Duduk}

Tulang punggung merupakan bagian tubuh yang memiliki peranan sangat besar dalam menjaga kestabilan tubuh. sebagian besar aktivitas sehari-hari dapat dilakukan dalam posisi duduk, sehingga penting untuk mengetahui posisi tubuh saat duduk yang benar untuk menjaga kesehatan tulang punggung

Posisi Duduk Yang Benar :

1. Duduk tegak dengan punggung lurus dan bahu ke belakang. Paha menempel di dudukan kursi dan bokong harus menyentuh bagian belakang kursi. Tulang punggung memiliki bentuk yang sedikit melengkung ke depan pada bagian punggung, sehingga dapat diletakkan bantal untuk menyangga kelengkungan tulang punggung tersebut.

2. Pusatkan beban tubuh pada satu titik agar seimbang. Usahakan jangan sampai membungkuk. Jika diperlukan, kursi dapat ditarik mendekati meja agar posisi duduk tidak membungkuk. 
3. Posisi lutut mempunyai peranan penting juga. Untuk itu tekuklah lutut hingga sejajar dengan pinggul. Usahakan untuk tidak menyilangkan kaki.

4. Jika dudukan kursinya terlalu tinggi, penggunaan pengganjal kaki juga membantu menyalurkan beban dari tungkai.

5. Jika ingin menulis tanpa meja, gunakanlah pijakan di bawah kaki namun posisi kaki tetap sejajar dengan lantai. Akan tetapi hal ini sebaiknya tidak dilakukan terlalu lama karena akan membuat tulang ekor menahan sebagian beban yang berasal dari paha.

6. Usahakanlah istirahat setiap 2 jam sekali dengan cara berdiri, peregangan sesaat, atau berjalanjalan di sekitar ruangan untuk mengembalikan kesegaran tubuh agar dapat tetap berkonsentrasi dalam belajar.

7. Tangan dibuat senyaman mungkin di atas meja, namun jangan lupa untuk mengistirahatkan lengan dan siku. Jika diperlukan, dapat menggunakan sandaran tangan untuk membantu mengurangi beban pada bahu dan leher anda agar tidak mudah lelah.
8. Jika ingin mengambil sesuatu yang berada disamping atau di belakang, jangan memuntir punggung. Putarlah keseluruhan tubuh sebagai satu kesatuan.

\section{Sikap Berdiri}

Ketika mengangkat, berjalan, atau melakukan kegiatan tubuh, keselarasan tubuh yang tepat penting untuk menjaga keseimbangan. Ketika tubuh seseorang di alignment yang benar, Semua otot bekerja sama untuk gerakan paling aman dan paling efisien, tanpa ketegangan otot.Ketika berdiri, berat badan sedikit ke depan dan didukung di bagian luar kaki. Sekali lagi, kepala tegak, punggung lurus, dan perut terselip. (ingat bahwa klien tempat tidur harus di sekitar posisi yang sama sebagai jika dia berdiri)

\section{Sikap Berjalan}

Berjalan kaki adalah salah satu latihan fisik benturan ringan yang bermanfaat bagi kesehatan. Selain bisa memperbaiki suasana hati, berjalan kaki juga membantu mengatasi depresi.

Cara berjalan yang baik adalah:

1. Biasakan berjalan dengan tubuh yang tegak. Walaupun setiap orang memiliki cara berjalan yang unik, ada sikap tertentu yang banyak orang 
lakukan saat berjalan, terutama dalam hal postur tubuh. Biasakan berjalan dengan punggung tegak dan mengangkat dagu agar sejajar dengan lantai.

2. Gunakan otot betis, paha belakang, dan kuadrisep agar Anda bisa berjalan dengan baik. Gerakan berjalan yang efektif melibatkan hampir semua otot tungkai, bukan hanya satu. Visualisasikan bahwa saat ini Anda sedang berjalan. Langkahkan kaki kanan ke depan dengan meletakkan tumit di lantai lalu gunakan otot paha belakang dan kuadrisep kaki kiri untuk menggerakkan tubuh ke depan sampai Anda bisa memindahkan tumit kiri ke depan. Biasakan melangkah dengan gerakan menggulung telapak kaki, yaitu mengangkat telapak kaki dimulai dari tumit sampai ke jari-jari kaki dengan arah lurus ke depan. Cara ini akan mengaktifkan otot betis sehingga telapak kaki membentuk sudut yang tepat saat terangkat dari lantai setiap kali Anda melangkah.

3. Tariklah kedua bahu sedikit ke belakang, tetapi biarkan tetap rileks. Saat berjalan, Anda akan lebih banyak mengandalkan otot kaki dan otot perut. Walau demikian, Anda harus tetap memperhatikan postur tubuh atas. Menarik bahu sedikit ke belakang dalam kondisi rileks akan banyak manfaatnya. Postur ini menjaga tubuh Anda agar tetap kuat dan stabil saat Anda meluruskan punggung dari leher sampai pinggul. Melakukan postur ini sambil menegakkan punggung dan mengangkat dagu akan mencegah ketegangan di punggung dan menghindari terjadinya cedera. Selain itu, cara ini membantu Anda membentuk kebiasaan berjalan yang baik sehingga tubuh Anda tidak bungkuk yang cenderung menimbulkan nyeri dan ketegangan bahu. Terakhir, dengan menarik bahu sedikit ke belakang, penampilan Anda akan lebih baik karena postur ini menunjukkan kepercayaan diri dan kekuatan.

4. Ayunkan lengan selama Anda berjalan. Mengayunkan lengan adalah hal biasa bagi banyak orang. Biarkan kedua lengan tergantung ke bawah secara alami. Saat mulai berjalan, lengan Anda akan berayun sedikit. Semakin cepat Anda 
berjalan, semakin lebar ayunannya.

Berjalan sambil mengayunkan lengan membantu Anda melangkah lebih lebar dengan energi metabolik yang sama besarnya seperti jika Anda tidak mengayunkan lengan.

\section{E. Cara Mengangkat beban}

1. Pemanasan : Sama halnya seperti olahraga yang mengharuskan pelakunya untuk pemanasan supaya terhindar dari cedera. Kemudian, jaga bagian kaki dalam posisi lebar atau terbuka. Tujuannya agar dapat menopang tubuh Anda saat mulai mengangkat barang. Posisi kaki harus kuat, sama halnya seperti posisi kuda-kuda dalam olahraga karate.

2. Jongkokan badan ke bawah, pastikan Anda membengkokan bagian pinggul dan lutut. Lipat satu kaki di depan dan lipat satu kaki lainnya di lantai, posisi ini biasa disebut half kneeling. Kondisikan posisi badan Anda agar selalu tegak karena dapat meluruskan tulang belakang. Angkat barang secara perlahan sambil meluruskan lutut dan pinggul Anda. Ketika mengangkat barang hindari gerakan memutar.
3. Angkat barang agar tetap dekat dengan bagian perut. Ketika mengganti arah, putar bagian pinggul terlebih dahulu kemudian bahu. Saat menurunkan badan jongkokan badan secara perlahan diikuti dengan bengkokan lutut dan pinggul.

Maka untuk menghindari tingginya tingkat kecelakaan atau cidera,gunakan posisi yang baik dan benar dalam segala posisi. Dalam peranan perawat sebagai pendidik, maka perawat harus bisa menjadi teladan yang baik bagi pasien. Ajarkan dan berikan informasi yang baik dan benar kepada pasien.

\section{PENUTUP}

Kenyamanan dan kesembuhan pasien adalah tujuan utama dari setiap RS, maka dengan kondisi ergonomic akan lebih membantu.Ergonomi adalah studi untuk menciptakan sistem kerja manusia yang lebih sehat, aman, dan nyaman.

Keperawatan merupakan profesi yang berfokus kepada pelayanan dan bertujuan membantu pasien mencapai kesehatannya secara optimal. Gerakan Keselamatan Pasien Rumah Sakit atau yang dikenal dengan sebutan patient safety merupakan suatu proses pemberian pelayanan rumah sakit terhadap pasien yang lebih aman. Proses ini mencegah terjadinya 
cedera yang disebabkan oleh kesalahan akibat melaksanakan suatu tindakan atau tidak mengambil tindakan yang seharusnya diambil.

Tujuan utama penerapan patient safety di rumah sakit adalah mencegah dan mengurangi terjadinya Insiden Keselamatan Pasien dalam pelayanan kesehatan. Kecelakaan di Rumah Sakit dapat disebabkan karena perilaku tidak aman. Salah satu cara yang dapat digunakan untuk mengurangi terjadinya kecelakaan di tempat kerja yaitu dengan adanya budaya keselamatan.Jadi, peran perawat dalam membantu pasien menerapkan hal yang ergonomis yang baik sangat penting di posisi berbaring,duduk,berdiri dan berjalan.

\section{DAFTAR PUSTAKA}

Cahyono, A. (2015). Hubungan karakteristik dan tingkat pengetahuan Perawat terhadap pengelolaan keselamatan Pasien di rumah sakit. Jurnal Ilmiah WIDYA, 1(1), 97- 99.

Fathi, A., \&Simamora, R. H. (2019, March). Investigating nurses' coping strategies in their workplace as an indicator of quality of nurses' life in Indonesia: a preliminary study. In IOP conference series: Earth and Environmental science (Vol.
248, No. 1, p. 012031). IOP Publishing.

Harus, B., D., \& Sutriningsih, A. (2015). Pengetahuan Perawat Tentang Keselamatan Pasien dengan Pelaksanaan Prosedur Keselamatan Pasien Rumah Sakit (KPRS) di Rumah Sakit Panti Waluya Sawahan Malang. 3(1), 25-27.

Ismainar, H. (2019). Keselamatan Pasien di Rumah Sakit. Yogyakarta : Deepublish.

Ishana Balaputra, A. H. (2017). Pengetahuan ergonomi dan postur kerja perawat pada perawatan luka dengan gangguan muskuloskeletal di dr. H. Koesnadi Bondowoso . BKM Journal of Community Medicine and Public Health,33(9), 445-448.

Najihah. (2018). Budaya Keselamatan Pasien dan Insiden Keselamatan Pasien Di Rumah Sakit: Literature Review. Journal of Islamic Nursing. 3 (1), 1-4.

Oesman, T.I. 2012. Intervensi Ergonomi pada Proses Stampping Part Body Component Meningkatkan Kualitas dan Kepuasan Kerja serta Efisiensi Waktu di Divisi Stampping Plant PT. ADM Jakarta 
(Disertasi). Denpasar: 40Program

Pascasarjana Universitas Udayana

Rio Yuwono, F. Y. (2015). ANALISA

FAKTOR K3 DAN ERGONOMI

TERHADAP. Jurnal Ilmiah Teknik

Industri, 14(1), 1-12.

Sri yulia,dkk. Peran perawat terhadap pelayanan keselamatan pasien.

Jurnal Indonesia, vol 15, no 3,

November hal 2012; hal 185- 192.

Sudarma,M.Adiputra,N.Manuaba,A.Sutjana,

IDP. 2012. Redesain Stasiun Kerja

yang Ergonomis dan Implementasi

TeknologiInformasi Meningkatkan

Produktivitas dan Kesehatan

Kerja Penyelaras Gamelan Bali.

Prosiding seminar Nasional

Ergonomi.Bandung: Program Studi

Teknik Industri-Universitas

Widyatama p.L25

Simamora, R. H. (2020). Learning of Patient Identification in Patient Safety Programs Through Clinical

Preceptor Models. Medico Legal Update, 20(3), 553-556.

Vena Jaladara, dkk. Hubungan tingkat pengetahuan dan praktik perawat mengenai keselamatan pasien (patient safety) di instalasi gawat darurat rs $\mathrm{X}$ semarang.Jurnal kesehatan masyarakat (eJournal) Volume 3, Nomor 1, Januari 2015 (ISSN 2356-3346) http://ejournals1.undip.ac.id/ind ex.php/jkm. 